\title{
ERRATA
}

\section{Isolation and Characterization of Rhodovulum strictum sp. nov. and Some Other Purple Nonsulfur Bacteria from Colored Blooms in Tidal and Seawater Pools \\ AKIRA HIRAISHI AND YOKO UEDA \\ Laboratory of Environmental Biotechnology, Konish Co., Yokokawa 5-6-3, Sumida-ku, Tokyo 130, Japan}

Volume 45, no. 2, p. 321, column 1, line 38: "straight-chain unsaturated and monosaturated" should read "straight-chain saturated and monounsaturated."

Page 325, column 2, lines 22 and 23: "Straight-chain unsaturated and monosaturated" should read "Straight-chain saturated and monounsaturated."

Determination of 16S rRNA Sequences of Streptococcus mitis and

Streptococcus gordonii and Phylogenetic Relationships among

Members of the Genus Streptococcus

YOSHIAKI KAWAMURA, XIAO-GANG HOU, FERDOUSI SULTANA, HIROAKI MIURA, AND TAKAYUKI EZAKI

Department of Microbiology, Gifu University School of Medicine, 40 Tsukasa-machi, Gifu 500, Japan

Vol. 45, no. 2, p. 407, Table 2, column 1, line 1, and column 2, boxhead: "S. mitis NCTC 10234" should read "S. mitis NCTC 12261."

\section{Validation of the Publication of New Names and New Combinations Previously Effectively Published Outside the IJSB: List no. 52}

Volume 45, no. 1, p. 197: "Paenibacillus pubuli" should read "Paenibacillus pabuli." 